\title{
The genus Epigloea in Poland
}

\author{
MIROSLAWA CEYNOWA-GIELDON
}

Department of Taxonomy and Plan: Geography, Nictolas Copernicus University Gagarina 9, PL-87.100 Torun

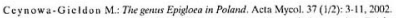

The paper presents a description, figures and locations of the species Epiglose plejaspora, E. bectraspong and $E$. soleiformis, new to Poland, found on the shores of lakes in the Tuchola Forests (Bory Tucholskic) region (NW Poland).

Key words: lichenizud Ascomycora, symtiosix semi-lichens, algal parasites, Epigloca, Tuchola Forests

\section{INTRODUCTION}

The genus Epigloea with the specics $E$. bactrospora Zukal had been determined in Austria (Oberösterreich, Salzburg). The author of description (Zuk al 1890) defined it as the lichen with gelatinous, homoiomerous thallus differing from more common and known gelatinous lichens in its algal partner. On the basis of species mentioned above, which for a long time was known from the Alps and the Crech Forest only, Zahlbruckner $(1907,1926)$ separated Fpigloeaceae from Pyrenocarpeae family of lichens. Later Dóbbeler (1984) included rich Grummann's material into Epigloea, with the genus described by this author as Vorarlbengia (Grummann 1968) and presented the diagnosis of 7 new Epigloea species. According to Dobbeler (1984) two or even three species of this genus remain in one location.

Epigloea has been mentioned in lichen determination keys for a long time ( $\mathrm{Lin}$ dau 1913; Poelt 1969; Poelt and Vèz, da 1981; Purvis et al. 1994) however there are some doubts concerning counting this genus among lichens. Grummann (1968) determed Epigloea bactrospora Zukal and the genus Vorarlbergia determined by himself as semi-lichens. Such a character of the genus is supported by observations of Epigloea bactrospora cultures. It appeared that alga - fungus relation in this species is not stable but changes depending on external environmental conditions. Fungus alga interrelations are a kind of fight, where one or the other partner wins. When environmental conditions favour fruiting thalli formation, Epigloea becomes, in the light of observations mentioned above, algal parasite ( $\mathrm{Jaag}$ and Thom as 1934). 


\section{MATERIAL METHODS AND RESERCH AREA}

The first species of Epigloea genus in Poland was found by chance during microscopic examination of gelatinous material containing pine pollen, collected in December 2000 on the Wielkie Gacno Lake, in the area of the Tuchola Forests National Park. The next year special researches of Epigloea fruiting bodies were undertaken on the sandy shores of the lake mentioned above and on some other water basins located on sandr, among pine forest, in the same north Poland region. Special attention was payed to gelatinous matter of overground algae. The algae samples were collected and exactly examined under microscope in the laboratory. The material containing fruiting bodies of the genus sought for was determined according to

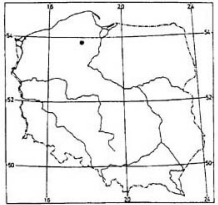

Fig. 1. Location of study area

Dobbeler (1984) key and deposited in the Herbarium of the Institute of Ecology and Nature Protection, Nicholas Copernicus University in Toruń (TRN). Drawing documentation of the species found was done under microscope by the use of drawing apparatus.

The research area was limited to the Tuchola Forests region (Fig. 1), which is one of the most interesting in floral respects in Polish lowland. The region is characterized by occurrence of numerous lakes and peat-bogs with rare, partly relict, flora. The material examined was collected on the shores of oligotrophic lakes mainly, which Lobelia dortmanna and Isoëtes lacustris.

Location list includes (in parenthesis) their situation in Poland on maps according to ATPOL grid square system (Zając 1978).

\section{DESCRIPTION}

Epigloea thallus composed of algal and fungal cells is shiny, almost Iransparent, dirty-green, gelatinous mass, closely adhering substratum. During drying out it becomes viscous and then forms fragile, shiny film. The main thallus components are $\pm \mathrm{el}$ lipsoidal algal cells, $2.5-10(-16) \times 1.2-7 \mu \mathrm{m}$, straight or slightly brown, surrounded by often layered, 4 (5) $\mu \mathrm{m}$ thick, gelatinous envelope (Fig. 2). The algae from Epigloea bacirospora culture were determined by Jaag and Thomas (1934) as Coccomyza epigloea. However it is difficult to differentiate them from Coccomyxa confluens (Kützing) Fott cells living in colonies devoided of fungus hyphae (Ettl and Gart. ner 1995). Apart from cells of the main genus Coccomyxa, Mesolenium macrococ. cum and other algae cells also often occur in Epigloea gclatinous matter with fungus hyphac. Besides, numcrous stranger bodies, like plant pollen grains or spores of other fungal species are found with in them. Epigloea forms among algae loose net, composed of delicate hyphae connected with algal cells. Hyphae overgrow gelatinous 


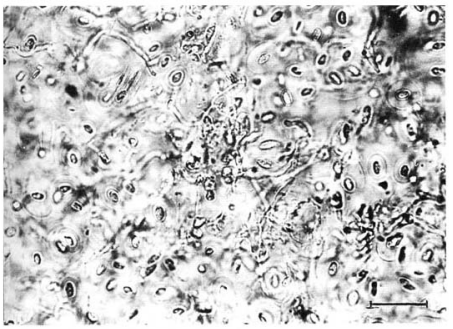

Fig. 2. The green alga of Cocconyxa with hyphac of Epigtea pleiesnom. Scale bat - $20 \mu \mathrm{m}$.

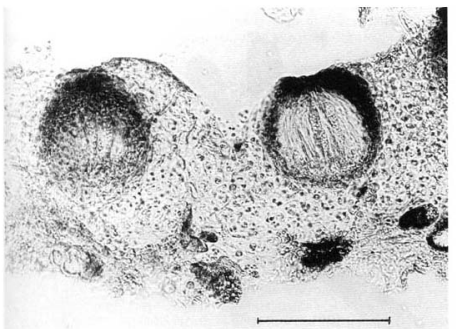

Fig. 3. Vertical section through thallus of Epigha plezispora. Scale bar - $100 \mu \mathrm{m}$. 


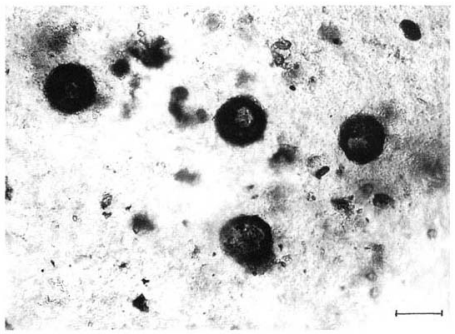

Fig. 4. Perithecia of Epiglea pleiospara. Scale bar - $80 \mathrm{~mm}$.

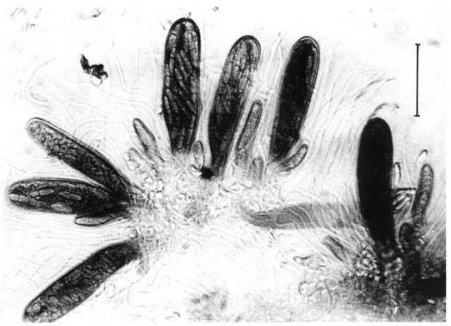

Fig. 5. Asci of Epigloe pleiospons (in Lugol's) Scale bar - $25 \mu \mathrm{m}$. 
algal envelopes and dip simple, beak-like haustoria into their cells. Before penetrating cells, at the joint with gelatinous envelope, hyphae form characteristic knobs or bubble-like callosities (Figs 6d-8d). Close to them, at the hyphae endings, sometimes dividing cells occur, testifying to favourable fungus influence on algal partner development.

Epigloea ascomata occur sometimes abundantly. Their structure at young and mature stage does not differ from typical perithecia. However in old specimens ostio$\mathrm{k}$, originating through louseness or unsticking of middle part of fruiting bodies, exceeds $2 / 3$ of their diameter (Fig. 3). Perithecia are more or less globose, partly or completely immersed in thallus, soft, often green-black, thicker and darker in the upper part (Fig. 4). Their walls are devoid of algal cells. Paraphyses numerous and thin, sometimes branched at the basis, with anastomosis. Asci - unitunicate, eight- or multispored, club-shaped to cylindrical, with longitudinal chin at the apex after ascospores spilling. Ascospores - colourless and thin-walled, ovoid-ellipsoid or bar-shaped, 1- to 5-septate, in some species with an appendage at both ends (Dobbeler 1984). Pycnidia, similar to fruiting bodies, sometimes develop among perithecia, are filled with gelatinous substance with numerous, terminal conidia - bacilliform to narrowly or broadly ellipsoid.

Epigloea develops on various substrata, strongly covered with algae. It occurs in wet places, on rocks, mosses, laying trees, lichens and raw humus.

Three Epigloea species were found during researches in the Tuchola Forests area. They were determined, according to Dobbeler (1984), on the basis of the following characteristics:

1. Asci multispored

2. Asci up to 32-spored; ascospores narrowly-ellipsoid, 2-3 $\mu \mathrm{m}$ thick; perithecia generally black-green, up to $150 \mu \mathrm{m}$ diam., often with black ring around the ostiole E. pleiospora

2.* Asci above 32-spored; ascospores bar-shaped, about $1.5 \mu \mathrm{m}$ thick; perithecia brown, $115 \mu \mathrm{m}$ diam., without black ring around the ostiole E. bactrospora

1.*Asci 8-spored. E. soleiformis

\section{Epigloea pleiospora Dōbb. (Figs 2-6)}

Perithecia globose, 75-150 (-160) um diam., black-green or black-blue, the wall 14-20 $\mu \mathrm{m}$ thick in the upper part, 7-10 $\mu \mathrm{m}$ at the bottom and in lateral parts. Ostiole 20-50 $\mu \mathrm{m}$ diam., often surrounded with clcarly scparated dark ring. Asci (40-) 45-65 (-75) x 9-12 $\mathrm{mm}, 32$-spored or less. Often one perithecium contains asci with different spore number (Fig. 5). Ascospores (5.5-) 6.5-9 (-11.5) x 2-3 $\mu \mathrm{m}$ (larger in asci less than 32-spored), narrowly-ellipsoid, with one septum.

Ascomata sunk into gelatinous matter covering mosses and wet sand with pine pollen sediment (Fig.4).

The species known so far from Bavaria (Oberbayern) only.

Localities in Poland (leg. M. Ceynowa-Giełdon): 1 - on W shore of Wielkie Gacno lake, on the area of the Tuchola Forests National Park (ATPOL grid square - CB44), on Polytrichum commune, P. strictum and Pohlia nutans, more rarely on Sphagnum and raw humus with Pinus sylvestris pollen sediment, together with Boeomyces nufus, 

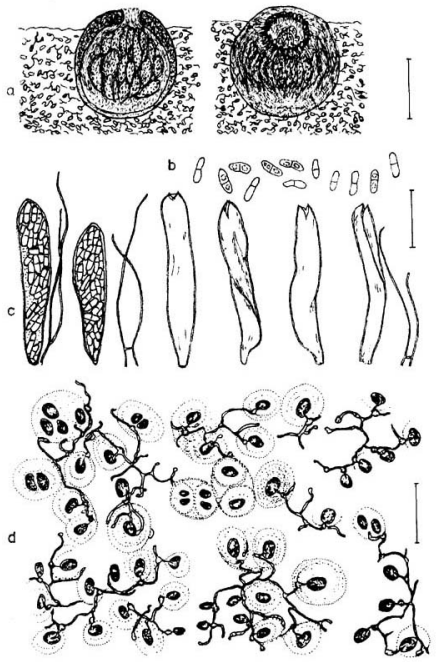

Fig. 6. Epidoea pleiospona Dübb. (original; locality: Tuchola Forests) a - perithecia; b - ascospores; $\mathrm{c}-$ asci and paraphyses (in Lugol's); $\mathrm{d}-$ the geen alga of Coccomyxa-typ and hyphae with haustoria of Epiglaea. Scale bars: a - $50 \mu \mathrm{m} ; \mathrm{b}-\mathrm{d}=20 \mu \mathrm{m}$ 
Placynthiella uliginosa and P. icmalea, 2.12.2000; 2 - on E shore of Piecki Duźc lake, near Laska village, $\mathrm{N}$ of city of Chojnice (CD33), on Sphagrum and grass remains, 14.09.2001; 3 - on felted tree emerging from Zmarte lake water, near Laska village (CD33), 14.09.2001; 4 - on E shore of Jezioro Piecki Malc lake near Laska village (CD33), on Sphagnum and vascular plants remains, 5.10.2001; 5-on sandy and peaty shore of Moczadło lake, near Mecikat (CB43), 15.09.2001.

\section{Epigloea bactrospora Zukal (Fig. 7)}

Perithecia globose or ovate, (65-) 75-115 (-130) $\mu \mathrm{m}$ diam., pale to dark brown, with fragile, sometimes transparent walls, occasionally surrounded by colourless, up to $8 \mu \mathrm{m}$ thick, gelatinous coat at the apex. Ostiole visible as a pale spot. Perithecium walls about 15 $\mu \mathrm{m}$ thick in the upper part, 7-10 $\mu \mathrm{m}$ at the basis and on lateral sides. Asci (30-) 40-55 (-60) × 9-12, above 32-spored. Ascospores (6-) 7-10 (-11.5) x 1.5 (-2) $\mu \mathrm{m}, 1$-septate, bar-shaped, with rounded or narrowing ends and under extreme conditions, according to Do. bbeler (1984) - spindle-shaped.

Ascomata placed on the surface or sunk into algal films on all possible substrata, c.g. dying mosses, squamules of Cladonia species, wood and bark of pine.

The species known until now from Germany, Austria, Italy (South Tirol) and Switzerland, mainly from the Alps, Czech Forest and Bavaria Forest, recorded at 700 - $1250 \mathrm{~m}$ above sea level (Grummann 1968; Döbbeler 1984).

Localities in Poland (leg. M. Ceynowa-Giełdon): 1 - on W shore of Wielkic Gacno lake, on the area of the Tuchola Forests National Park (CB44), 7.10.2001; 2 - on S shore of Gluche lake in the Tuchola Forests National Park, on dcad remains of Sphagrum and Polytrichum mosses, on squamules of Cladonia species and Hypogymnia physodes thallus, together with Botrydina and Absconditella sphagnorum, 13.09.2001.

\section{Epigloea soleiformis Döbb. (Fig. 8)}

Perithecia globose, (70-) 90-140 (-150) $\mu \mathrm{m}$ diam., often with depression around the ostiole, black-grecn or black-grey, with colourless gelatinous coat 4-15 $\mu \mathrm{m}$ thick. Asci

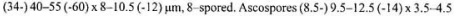
$(-5) \mu \mathrm{m}, 1-$ septate, ellipsoid, with a slight eonstrietion in the middle.

Ascomata on, or immersed in algal films, on lichens or decomposing mosses, rareIy on raw humus, rotten wood or acid rocks.

The species known till now from south Sweden (Sa n tes son 1993), Great Britain, Germany, Austria, Italy (South Tirol), and the subantarctic Marion Island ( $\mathrm{Pu}$. rv is et al. 1994). Locus classicus and the majority of these species localities known so far occur in the Alps area.

Localities in Poland (leg. M. Ceynowa-Gieldon): 1 - on W shore of Wielkie Gacno lake, on the area of the Tuchola Forests National Park (CB44), associated with Tren. tepohila, 7.10.2001; 2 - on the Piecki Duże lake, ncar Laska village (CB33), on squamules of Cladonia and dying plant remains, together with Absconditella sphagnorum and Placynthiella uliginosa. 

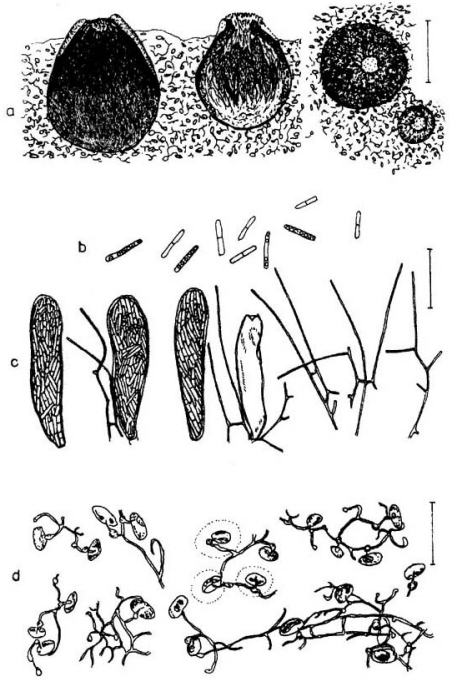

Fig, 7. Eptgioen bactrospora Zukal. (original; locality: Tuchola Foresis) a - perithecia; b-ascospores; c-mature and dehisced asei and paraphyses (in Lugol"s); $d$ - the geen alga of Coccomyxa-lyp and hyphae with hatustoria of Episloea. Scale bars: a $-50 \mu \mathrm{m} ; \mathrm{b} \cdot \mathrm{d}-20 \mu \mathrm{m}$. 

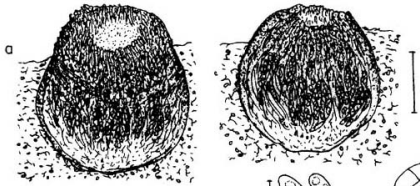

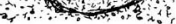

b
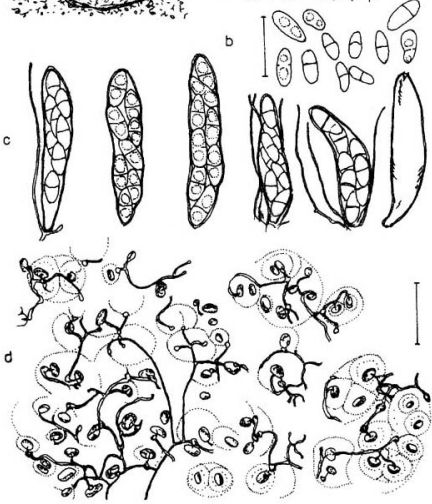

Fig. 8. Epigioea soletformis Dchb. (original; locality: Tuchola Forests) a - perithecia; b-ascospores; $c-$ asci and paraphyses (in Lugol's); $d$ - the geen alga of Coccomyza-typ and hyphae with haustoria of Epigfoea. Scale bars: a $-50 \mu \mathrm{m} ; \mathrm{b}-\mathrm{d}-20 \mathrm{~mm}$. 


\section{REMARKS}

Most of the research material examined was sterile material visible under microscope as delicate hyphae characteristically connected with the alga Coccomyra cells. Solely sterile thalli of Epigloea were found among others on the lakes: Nawionek and Czame near Laska place and on the Moczadło Lake near Męcikał. Unidentified species of Epiogioea genus developed on felled trees, more rarely on sandy shores and bark of Juniperus communis shrubs and Pinus sylvestris trees, growing near water table. Exceptionally such sterile thalli were found on silvan roadside near Widno place.

The frequent absence of fruiting-bodies hindering species determination can point to their special ecological demands including possible substratum - dependence. Similar situation concerns some Epigloea species in Bavaria Forest, on the Alps margin (Grummann 1969; Dobbeler 1984). Epigloea was found in the mountains in Germany, Austria, Switzerland and Italy, most frequently on the lakes but in fir or spruce forest. May be species of this genus are to be found also in Polish mountains. The similarity of Epigloea from Polish localities and those known for a long time from Austria, near locus classicus of $E$. bactrospora specics can be also indicative of concomitant species, including Mesotaenium macrococcum (Kützing) Roy et Bisselt alga, described carlier as M. Braunii.

In some algal colonics of Coccomyxa genus studied in the Tuchola Forests area, the competition was stated between very delicate Epigbea hyphae and Omphalina hyphae, a lichenized basidiomycetc. The competition resulted in formation of "Botrydina" - type thallus and limited development of Epigloea hyphae, penetrating the same algal colony.

The lichen nature of Epigloea species is controversial, connected to a large extent with the definition of lichens. According to Döbbeler (1984) the species of the ge. nus described above can be interpreted as "highly adapted algal parasites". I think that specialistic studies of the structure and interesting biology of these species can elucidate evolutionary mechanisms of lichens genesis.

\section{REFERENCES}

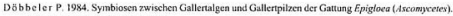
Beih, Nova Hedwigia 79: 203-239.

Eftl H., Gartner G. 1995. Sylabess der Boxien-, 1.uft- uad Fechtenalgen. Gustav Fischet Verlag. Stutigart Jena. New York.

G r umma an V.J. 1968. Alte und neue Halbhechten. Fin neucr Flechtenparasit. Placynthium a sperellium ncu fû́ Mitteleuropa. Sydowia 22:216-224.

Jaag O, Thom as E. 1934. Neue Untersuchungen uber die Flechte Epigloea hactrospora Zukal. Ber. Schweiz. Bot. Ges, 43 (1): $77-89$.

Lin da u G. 1913. Die Flechten. Mit 306 Figuren im Text. Berlin. Verlag von Julius Springer.

Poelt J. 1969. Bestimmungsschl usssel europaischer Flechten. J. Cramer, Lehre.

Poelt J., VEzda A. 1981. Bestimmungsschlïssel europiaischer Flechten. Ergaincungsheft II. Bibl. Lichenot. 16. J. Cramer, Vaduz.

Purvis O. W., Coppis B. J., Hawksworth D. L. Janes P. W., Moore D. M., 1994. The lichen flora of Great Britain and Ireland. Natural History Museum Publitations in association with The British Lichen Society. Ed. 2. St. Edmundsbury Press, London.

Santesson R. 1993. The lichens and lichenicokous fungi of Sweden and Nonway. SBT-forlaget, Lund.

Zahlbruekner A. 1907. Lichencs (Fiechten), B. Specieller Teil. (In:) A. Engler, K. Prantl (cds) Die natirlichen Pflanzenfamilien L.: 49-249. Leipzig Verlag von Wilhelm Engetmann. 
Zahlbrueknet A. 1926. Licheres (Flechten), B. Spezieller Teil. (ln:) A. Engle f, K. Prantl (cds) Die naturlichen Pflarvenfamilien. Ed. 2. Vol. 8: 61-270. Leipzig Veriag von Wilhelm Engelmann.

Zuka| H. 1890. Epig'oea bectrospora. (Einc neve Gallectfechte nit chlorophyllhältigen Gonidiea). Osterr. Bot, Z. 40, 323-328.

Zając A. 1978. Allas of distribution of vascular plants in Potand. ATFOL. Taxon 27: 481-484.

\section{Rodzaj Epigloea w Polsce}

\section{Streszczenic}

Trzy gatunki nowego dlat Polski, todzaju Epigloca, noszzcego charakter póporostu, stwierdzono w Regienie Horów Tuchdskich, w po'udniowej exestei wojewbitzwa pomorskiego. Są nimi: Epigloea plelospore, E. bactrospona i $E$. soleiformis - taksony rózniace się miçdzy sobą m. in. liczta zarodników w workach. Zasleciono je na obumicrajacych metheh i szezlkach roslin naczynowyeh, na piaszezystyeh i lekko zatorfionych bragach, nicktórych, przeważaic oligotreficznych, jezior śródlénych. Więksaóš dotychczas znavych stanowisk wymienionych gatanków znajduje się w Alpoch i ta obrzež $\mathrm{Alp}$, dlatego można spodziewat się malezienàa ich rốwaież w gúrach poludniowej Polski.

Perytecja gatunków z rodzaju Epigloed tkwią w bnudnozielonsj, galaretowatej masie glonów z rodzaju Coccomyxu przercśniętej przez delikatre strzępki grzyba. Koăce tych sirz̨̨pek wija się wśrodd galaretowatych otoczek i zapuszczaja do wnętrza komćrek gloau charakterystyczne haustoria (Figs 6d-8d). Podezas prowadzonyeh badari stykano się najezęsistej z plornymi plectarni Epigłoea, Owoeniki wyzej proedstawionych gatunkủw, w nicktỏrych micjscach bardzo licznc, stwicrdzono w siosunkowo nielicznych próbach bada wecycha. 